\title{
Microbial Diversity Assessment by PCR-DGGE Analysis in National Sanctuary of Ampay in Perú
}

\author{
Raquel A Ccoscco ${ }^{1}$, Victor H Sarmiento ${ }^{2}$ and Gretty K Villena*1 \\ ${ }^{1}$ Laboratorio de Micología y Biotecnología, Universidad Nacional Agraria La Molina, Perú \\ ${ }^{2}$ Universidad Nacional Micaela Bastidas de Apurímac, Perú
}

Submission: August 11,2018; Published: September 20, 2018

*Corresponding author: Gretty K Villena, Laboratorio de Micología y Biotecnología, Universidad Nacional Agraria La Molina, Av. La Molina s/n, Lima 12, Perú, Tel: +51-1-6147800, Ext. 463; Email: gkvch@lamolina.edu.pe

\begin{abstract}
Microbial diversity analysis by means of PCR- DGGE fingerprinting was conducted for water and sediment samples of the National Sanctuary of Ampay in Perú. This wildlife conservation area is not disturbed by human activity and this study corresponds to the first report of microbial diversity. PCR DGGE was able to detect culturable and non-culturable bacteria and fungi. The Predominant bacterial genus in water and sediment was Pseudomonas. Fungal community was more diverse. Aspergillus species were mainly distributed in water. Sediment samples contain different fungi genera, including a non-culturable Pleosporales specie. Because the bacterial and fungal diversity found, the Sanctuary of Ampay in Peru is a very valuable natural environment for bioprospecting of new genes of enzymes and natural compounds for different biotechnological applications.

Keywords: Genes; DGGE-PCR analysis; Water samples; Enzymes; Biotechnological applications;
\end{abstract}

\section{Introduction}

Culture based methods to evaluated microbial diversity are usually unsuccessful because only $0.1-1 \%$ to $1-10 \%$ of microbial species can growth in vitro and different microbiological and molecular strategies have been considered to improve microbial cultivation $[1,2]$.

In the last years, culture-independent techniques had become the main tools for evaluation of taxonomic and functional structures of microbial communities. Either $16 \mathrm{~S}$ rRNA amplicon-based metagenome sequencing or shotgun metagenome sequencing is largely used for the assessment of the microbial diversity. Recently, comparison of two nextgeneration sequencing techniques, amplicon and shotgun, in Brazilian river food plain systems showed that less than $50 \%$ of phyla identified via amplicon sequencing were recovered from shotgun sequencing [3]. Amplicon based metagenome sequencing are commonly performed by analyzing the prokaryotic 16S ribosomal RNA gene (16S rRNA), which is approximately $1,500 \mathrm{bp}$ long and contains nine variable regions interspersed between conserved regions. Variable regions of 16S rRNA are frequently used in phylogenetic classification such as genus or species in diverse microbial populations. Improving on the amplicon sequencing techniques remain as challenge $[4,5]$.

Between traditional and high accurate techniques for microbial diversity assessment, Denaturing Gradient Gel
Electrophoresis, (DGGE) is an inexpensive fingerprinting technique and could be employed for several applications, including analysis of complex communities, monitoring of population shifts, and sequence heterogeneities. Through DGGE it is possible to obtain taxonomic information because bands can be excised, re-amplified and sequenced [6]. DGGE is still the chosen technique to assess microbial community composition in different natural or artificial ecosystems and foods $[7,8]$. Natural ecosystems comprise several microbial habitats including thermal water, water ponds, microbial mats and sediments. Metagenomic study of this habitats produced huge information, providing holistic images of the microbial communities. Peru has several conservancy areas distributed across marine, coast, andean and jungle ecosystems but there is not any report of microbial diversity by metagenomic approach.

National Park of Ampay Santuary is placed in Apurimac, in the south Andes ( $13^{\circ} 34^{\prime} 44^{\prime \prime} \mathrm{S}, 72^{\circ} 53^{\prime} 24^{\prime \prime} \mathrm{W}$ ) and has forest, several water ponds and two hot springs. This place is very attractive for biodiversity studies, since is considered as conservation area. Thus, natural environments are not disturbed by human activity and biodiversity analysis has the advantage to reflect natural microbial community structure.

Despite of the valuable ecological information obtained by biodiversity analysis, the deep knowledge of structure 
of microbial communities allows several biotechnological applications such as discovery of new genes encoding for enzymes, secondary metabolites and others.

\section{Materials and Methods}

\section{Sample collection}

Samples were collected from hillside water pond and surrounding sediment of "Carbon cañana", located in National

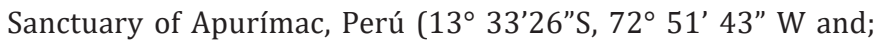
$3255 \mathrm{~m}$ high). Environmental and water temperatures were 14 ${ }^{\circ} \mathrm{C}$ and $20{ }^{\circ} \mathrm{C}$ respectively.

\section{DNA extraction}

To extract the DNA from water samples, one liter of water was vacuum filtered with nylon membrane $(0.2 \mu \mathrm{m}$ pore size and $47 \mathrm{~mm}$ diameter). Then, the membrane was cut in small pieces and put them into one $2 \mathrm{ml}$ tube. On the other hand, the sediment sample was transferred into a $50 \mathrm{ml}$ tube, centrifuged (5000 rpm, $15 \mathrm{~min}$ ), and desiccated. Both, water and desiccated sediment samples were stored at $-80^{\circ} \mathrm{C}$ until their DNAs were extracted.

The DNA from water sample was extracted according to Ludeña method [9], with some modifications as follows: cells were removed from filter with a vortex in $500 \mu \mathrm{L}$ of a TES buffer (10mM Tris, 1mM EDTA, pH 8, and 25\% (w/v) of sucrose) for $15 \mathrm{sec}$. Then, the liquid phase was recovered into other $2 \mathrm{ml}$ microtube and treated with $60 \mu \mathrm{l}$ of lyzozyme $(5 \mathrm{mg} / \mathrm{ml})$ and 50 $\mu \mathrm{l}$ of $0.25 \mathrm{M}$ EDTA at $37{ }^{\circ} \mathrm{C}$ for $15 \mathrm{~min}$. RNA was eliminated by adding $175 \mu \mathrm{l}$ of $\mathrm{H} 20,7.5 \mu \mathrm{l} 10 \%$ (w/v) SDS, and $10 \mu \mathrm{l}$ of $10 \mathrm{mg} / \mathrm{ml}$ RNAase to the mix, homogenized by vortex $2 \mathrm{sec}$ and incubated at $37^{\circ} \mathrm{C}$ for $30 \mathrm{~min}$ ). To complete the lysis process $10 \mu \mathrm{l}$ of $10 \mathrm{mg} /$ $\mathrm{ml}$ proteinase $\mathrm{K}$ was added and incubated at $37{ }^{\circ} \mathrm{C}$ for $30 \mathrm{~min}$. The proteins and cell debris were precipitated by adding $90 \mu \mathrm{l}$ of TE (10 mM Tris base, 1mM EDTA, pH 8), $120 \mu$ of $5 \mathrm{M} \mathrm{NaCl}$ (5M); and the mix was homogenized and incubated at $65^{\circ} \mathrm{C}$ for 25 min. In addition, 8M Potassium acetate solution $(75 \mu \mathrm{l})$ was used to concentrate the sample, by incubation at $4{ }^{\circ} \mathrm{C}$ for $15 \mathrm{~min}$ and centrifugation at $13500 \mathrm{rpm}$ for $5 \mathrm{~min}$. The supernatant was collected, and centrifuged at $13500 \mathrm{rpm}$ for $5 \mathrm{~min}, 3$ times. The DNA was precipitated using $0.6 \mathrm{~V}$ of isopropanol, incubating at $-20^{\circ} \mathrm{C}$ for $30 \mathrm{~min}$. After centrifugation at $13500 \mathrm{rpm}$ for $15 \mathrm{~min}$, the DNA pellet was washed with $70 \%(\mathrm{v} / \mathrm{v})$ ethanol, and centrifuged at $13500 \mathrm{rpm}$ for $15 \mathrm{~min}$. Finally, The DNA was dissolved in $25 \mu \mathrm{l}$ of free-nucleases water, and stored at $20^{\circ} \mathrm{C}$.

DNA extraction method from sediment sample was adapted from Lai, et al. [10], Zhou, et al. [11] \& Murray, et al. [12] 300mg of sediment were transferred to $2 \mathrm{ml}$ tube, and $810 \mu \mathrm{l}$ of Extraction buffer $(100 \mathrm{mM}$ Tris-HCl, 100mM EDTA, $100 \mathrm{mM}$ sodium phosphate, $1.5 \mathrm{M} \mathrm{NaCl}, \mathrm{pH} 8$ ), $90 \mu \mathrm{l}$ of $20 \%$ (w/v) SDS, and $117 \mu \mathrm{l}$ of $10 \%(\mathrm{v} / \mathrm{v})$ CTAB were added. The mix was homogenized by inversion for $1 \mathrm{~min}$ and incubated at $68^{\circ} \mathrm{C}$ for 1 hour, every $15 \mathrm{~min}$ the sample was homogenized by inversion, and centrifuged at $13500 \mathrm{rpm}$ for $5 \mathrm{~min}$, and the upper solution was transferred to a clean tube. This step was done for two samples by separate. The purification step was performed by adding 1 part of chloroform to each tube. Then, they were homogenized by inversion and centrifuged at $13500 \mathrm{rpm}$ for $10 \mathrm{~min}$. The upper solution was transferred to a new $2 \mathrm{ml}$ tube. RNA digestion was performing by adding $15 \mu \mathrm{l}$ of $10 \mathrm{mg} / \mathrm{ml}$ RNase to each tube and incubated at $37^{\circ} \mathrm{C}$ for $30 \mathrm{~min}$. The proteins were digested by adding $10 \mu \mathrm{l}$ of $20 \mathrm{mg} / \mathrm{ml}$ proteinase $\mathrm{K}$.

After that, the solution was homogenized by inversion and incubated at $37{ }^{\circ} \mathrm{C}$ for $30 \mathrm{~min}$. Precipitation of the CTAB-DNA complex was done by adding $250 \mu \mathrm{l}$ of $2 \mathrm{X}$ CTAB (1.4M NaCl, 0.1 M EDTA y $2 \%(w / v)$ CTAB) to each tube, and they were incubated at $68{ }^{\circ} \mathrm{C}$ for $15 \mathrm{~min}$. The CTAB-DNA complex was precipitated by adding 2.2 volumes of precipitation solution $(0.5 \%(\mathrm{w} / \mathrm{v})$ $\mathrm{CTAB}$ and $0.04 \mathrm{M} \mathrm{NaCl}$ ) and incubating for 1 hour in ice. Samples were centrifuged at $3000 \mathrm{rpm}$ for $5 \mathrm{~min}$, and the upper solution was discarded. $300 \mu \mathrm{l}$ of $1.2 \mathrm{M} \mathrm{NaCl}$ was added to each tube to dissociate the CTAB-DNA complex. The solution of each tube was mixed in only one. Finally, The DNA was purified by adding 1 volume of chloroform and centrifuged at $13500 \mathrm{rpm}$ for $15 \mathrm{~min}$. The supernatant was recovered in a $1.5 \mathrm{ml}$ tube. The DNA was precipitated in 0.6 volume of isopropanol and incubated at -20 ${ }^{\circ} \mathrm{C}$ for $1 \mathrm{~h}$. After the DNA precipitation at $13500 \mathrm{rpm}$ for $15 \mathrm{~min}$, the pellet was washed with $70 \%(\mathrm{v} / \mathrm{v})$ ethanol, solubilized in $20 \mu \mathrm{l}$ free-nuclease water, and stored at $-20^{\circ} \mathrm{C}$.

\section{PCR amplification of 16 and 18 S rRNA genes}

$16 \mathrm{~S}$ and $18 \mathrm{~S}$ rRNAs were amplified by PCR with primers showed in Table 1. Temperature gradient with different temperature intervals was performed to find out the optimal temperature of annealing for Bacteria and Archaea (from $48^{\circ} \mathrm{C}$ to $65^{\circ} \mathrm{C}$ ) and Eukarya (fungi) (from $40{ }^{\circ} \mathrm{C}$ to $60^{\circ} \mathrm{C}$ ).

Table 1: PCR-DGGE primers used for specific the amplification of 165 rRNA genes of Bacteria or Archaea, and 18S rRNA genes of Eukarya.

\begin{tabular}{|c|c|c|c|}
\hline Domains & Primer & Sequences $\left(5^{\prime} \rightarrow 3^{\prime}\right)$ & References \\
\hline \multirow{6}{*}{ Bacteria } & $* 968 \mathrm{~F}$ & AACGCGGAAGAACCTTAC & $\begin{array}{c}\text { Nubel et al. } \\
\text { [13] }\end{array}$ \\
\hline & $1401 \mathrm{R}$ & CGGTGTGTACAAGAAGACCC & \\
\hline & $1055 \mathrm{~F}$ & ATG GCT GTC GTC AGC T & $\begin{array}{l}\text { Wang et al. } \\
2008\end{array}$ \\
\hline & $1406 \mathrm{R}^{*}$ & ACG GGC GGT GTG TAC & \\
\hline & F16SrRNA* & CCTACGGGAGGCAGCAG & $\begin{array}{c}\text { Lai et al. } \\
\text { [10] }\end{array}$ \\
\hline & R16S rRNA & ATTACCGCGGCTGCTGG & \\
\hline \multirow[b]{2}{*}{ Archaea } & $0348 \mathrm{~F}^{*}$ & TCC AGG CCC TAC GGG & \multirow{2}{*}{$\begin{array}{l}\text { Achenbachy } \\
\text { Woese, et } \\
\text { al. [15] \& } \\
\text { Watanabe et } \\
\text { al. [16] }\end{array}$} \\
\hline & 0691R & GGA TTA CAR GAT TTC AC & \\
\hline \multirow{2}{*}{$\begin{array}{l}\text { Eukarya } \\
\text { (Fungi) }\end{array}$} & NS1 & GTAGTCATATGCTTGTCTC & \multirow{2}{*}{$\begin{array}{c}\text { Das et al. } \\
\text { [17] }\end{array}$} \\
\hline & NS1 & GTAGTCATATGCTTGTCTC & \\
\hline
\end{tabular}

${ }^{*}$ GCclamp

(CGCCCGCCGCGCCCCGCGCCCGGCCCGCCGCCCCCGCCCC) [16]. 
PCR mix (final concentration) for $50 \mu \mathrm{l}$ of volume reaction contained: PCR buffer $1 \mathrm{x}, \mathrm{MgCl} 2$ (2.5mM), dNTP's $(0.5 \mathrm{mM}$ for each one), primers $\mathrm{F}$ and $\mathrm{R}(0.2 \mathrm{mM}$ for each one), Go Taq Promega $(1.875 \mathrm{U} / 50 \mu \mathrm{l})$, metagenomic DNA (100 ng/50 $\mu \mathrm{l})$.

PCR thermal cycles include: 1 cycle of denaturation at 94 ${ }^{\circ} \mathrm{C}, 35$ cycles of $1 \mathrm{~min}$ denaturation at $94{ }^{\circ} \mathrm{C}, 1 \mathrm{~min}$ for annealing (optimal temperature varies for each primer set) and $2 \mathrm{~min}$ of extension at $72{ }^{\circ} \mathrm{C}$. The final extension was performed at $72{ }^{\circ} \mathrm{C}$ for $10 \mathrm{~min}$.

\section{Denaturing Gradient Gel Electrophoresis (DGGE)}

DGGE analyses was performed according to Green et al. [14] using a Cleaver scientific $₫$ equipment. The PCR products were loaded on $7 \%(\mathrm{w} / \mathrm{v})$ polyacrylamide gels and run with $1 \mathrm{X}$ TAE $(40 \mathrm{mM}$ Tris acetate, sodium acetate $20 \mathrm{mM}$, and $1 \mathrm{mM}$ EDTA pH 8). The polyacrylamide gels were made with denaturing range from $36 \%$ to $65 \%$ (Bacteria and Archaea) and from 25\% to $55 \%$ (Fungi). A $100 \%$ UF solution was defined as $40 \%(\mathrm{v} / \mathrm{v})$ formamide and 7.0 M urea. The DGGE was conducted at $60{ }^{\circ} \mathrm{C}$ $160 \mathrm{~V}$ for $3.5 \mathrm{~h}$ (for $16 \mathrm{~S}$ rDNA amplicons), and at $56{ }^{\circ} \mathrm{C}, 50 \mathrm{~V}$ for $16 \mathrm{~h}$ (for 18S rDNA amplicons). After the electrophoresis, the gel was stained with Gel Red ${ }^{\mathrm{TM}}$ for $30 \mathrm{~min}$. The stained gel was immediately photographed (ChemiDoc XRS-BioRad).

\section{DGGE PCR}

DNA bands from the DGGE gel were cut and put in $600 \mu \mathrm{l}$ tubes, then, submerged with $30 \mu$ l of ultrapure free-nuclease water. The DNA was allowed to passively diffuse into water at 37 ${ }^{\circ} \mathrm{C}$ for $30 \mathrm{~min}$, and then at $4{ }^{\circ} \mathrm{C}$ overnight [15]. Aqueous phase for each band was recovered in $1.5 \mathrm{ml}$ tube and stored at $4{ }^{\circ} \mathrm{C}$ $5 \mu \mathrm{l}$ of aqueous phase was used as template for PCR reaction with conventional rRNA gene primers without clamp (Table 1), following the same conditions of metagenomic DNA PCR.

\section{Sequence analysis}

DGGE-PCR amplicons were sequenced in MACROGEN (South Korea). The sequences obtained were analyzed with BLAST program of the National Centre for Biotechnology Information (NCBI) Phylogenetic tree was constructed by Neighbor-joining method from MEGA7 software.

\section{Results and Discussion}

DGGE analysis, a molecular culture independent method for assessment of microbial diversity was performed with hill inside water and sediment samples from National Sanctuary of Ampay in Perú.

This is the first report of microbial diversity in this wildlife conservation area, although previous reports on faunal inventory of Satyrinae butterflies and diversity of arboreal biomass were published $[16,17]$.

To evaluate the microbial diversity of water and sediment samples, some protocols for metagenomic DNA extraction were standardized to obtain both, better yield and quality of DNA. DNA recovery was as tenfold (10 x) higher from sediment samples compared with water samples. Yields for DNA extraction were $2 \mu \mathrm{g}$ per liter of water and $6 \mu \mathrm{g}$ per gram of sediment (dry weight). As expected, DNA quality from water samples was better; since sediment and soils commonly have humic acids which co precipitate with nucleic acids $[18,19]$. Also, the average size of the metagenomic DNA obtained from both types of samples was up to $18 \mathrm{Kbp}$, which was comparable with other optimized methods [20].

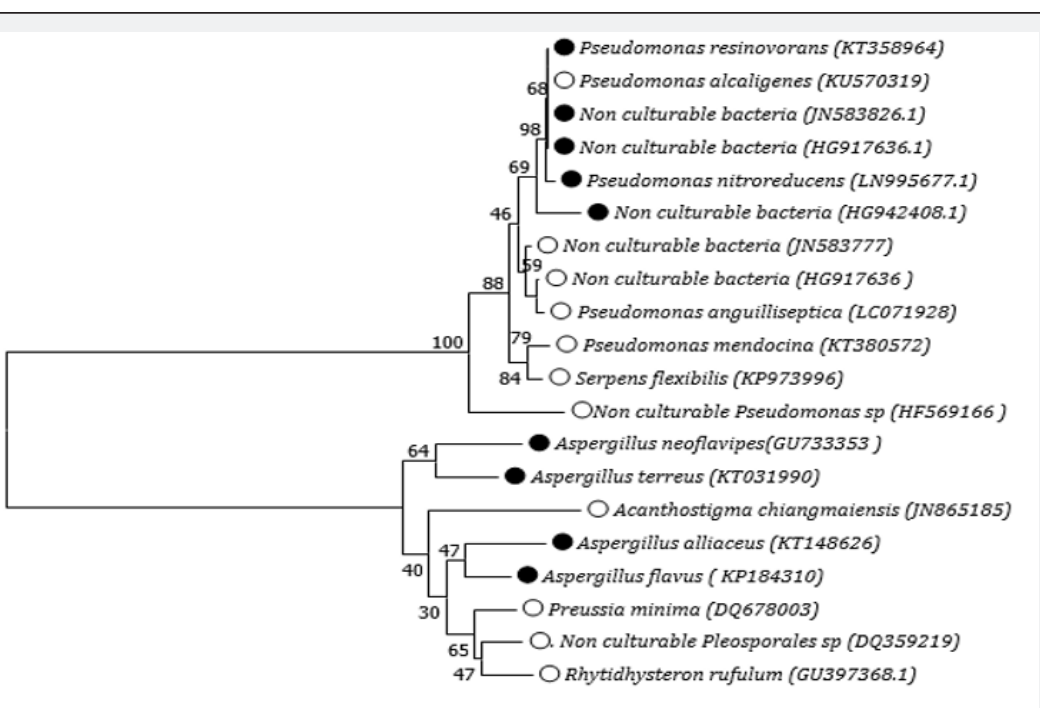

0.05

Figure 1: Phylogenetic tree of bacteria and fungi of water and sediments samples of the National Sanctuary of Ampay. Construction was based on the Neighbor-Joining algorithm of $16 \mathrm{~S}$ and $18 \mathrm{~S}$ ribosomal genes. The accession number of GenBank reference sequence is indicated in parenthesis. The tree was built with the use of MEGA7 software, with the $p$-distance model and 500 start replicas. The numbers in the nodes of each branch represent the start values. The bottom bar $=0.05$, indicates the number of base substitutions. Empty circles correspond to the water samples while filled circles refer to sediment samples. 
For PCR-DGGE, reference primers were used for amplification of a fragment of the 16S rRNA genes, 23S rRNA and 18S rRNA belonging to bacteria, archaea and eukarya (fungi). For each pair of primers, a gradient temperature PCR was done in order to obtain the optimal annealing temperatures $\left(48{ }^{\circ} \mathrm{C}\right.$ for GC968F/1401R and 1055F/ 1406R-GC, $55{ }^{\circ} \mathrm{C}$ for F16SrRNA-GC/ R16S rRNA and $55{ }^{\circ} \mathrm{C}$, NS1/ GC-Fung). No amplification was obtained for the 16S rRNA target sequences of archaea, since these sequences belong mainly to methanogenic archaea [16]. Although r16SRNA target sequences for Archaea were limited to few phyla, more sequences have been validated in the past years [21-24]. Bacterial and fungal diversity found in water and sediment samples of Ampay are showed in Figure 1. The most prevalent bacterial genus in water and soil was Pseudomonas, which is widely distributed in the environment [25]. Species of Pseudomonas comprised culturable and non-culturable strains. Non culturable bacteria refers to microorganisms with low viability because any stress factor in their environment limits their growth on the routine bacteriological media but are still able to show metabolic activity [26].

Common species found in Ampay include P. resinovorans and P. nitroreducens in sediment and P. alcaligenes in water respectively. P. resinovorans could be a rare human pathogen but also has biotechnological importance as lipase producer as well as P. resinovorans for the vanillin production and carbazol degradation [27-30]. Another detected bacteria in sediment, Pseudomonas nitroreducens, has a great metabolic capability for the catabolism of aromatic compounds [31].

Other species in water samples include Serpens flexibilis, recently renamed as Pseudomonas flexibilis [32] and P. mendocina an inhabitant of soil and water environments and previously reported also as an opportunistic human pathogen [33]. Interestedly, P.mendocina strains were recently reported as cellulase and medium-chain-length polyhydroxyalkanoate producers [34,35]. Finally, Pseudomonas anguilliseptica has been reported as a potential fish pathogen [36]. Because nonhuman activity has taken place in hill inside water in Ampay, strain identification should be confirmed.

With respect with the fungal diversity, the prevalent genus in sediment samples was Aspergillus. Even fungi are predominantly saprophytic, some of them are also considered as opportunistic species. Aspergillus flavus is a crop contaminant and aflatoxin producer [37], Aspergillus flavipes was recently studied for cytochalasans production and Aspergillus terreus which is the main producer of lovastatin, a cholesterol-lowering commercial drug [38,39].

Water samples showed more diverse genera of fungi. Those include: The new aquatic specie Acanthostigma chiangmaiensis [38], the endophytic specie Preussia minima which produces amylases and the Ascomycete, pan tropical specie, Rhytidhysteron rufulum [40,41]. Also, non-culturable species were detected, belonging to the Pleosporales, which comprises epiphytes, endophytes or parasites of plant, insect and liquens [42-44].

\section{Conclusions}

According to the overall species and metabolic diversity found in water and sediment by PCR-DGGE analysis, the Sanctuary of Ampay, constitutes an environment with high potential for bioprospecting of new genes of enzymes and natural compounds with biotechnological applications. The use of culture independent methods, as DGGE, to recover DNA directly from the environment, avoids the manipulation of opportunistic or pathogenic strains, allowing a safe use of genes related to metabolic diversity in natural environments.

\section{Acknowledgement}

This work was supported by Programa Nacional de Innovación para la Competitividad y Productividad- Innóvate Perú, through the grant № 143-FINCyT-IB-2013.

This article is dedicated in memory of Dr. Marcel GutiérrezCorrea, great mentor.

\section{References}

1. Amann RL, Ludwig W, Schleifer Karl (1995) Phylogenetic identification and in situ detection of individual microbial cell without cultivation. Microbiol Rev 59(1): 43-69.

2. Prakash O, Shouche Y, Jangid K, Kostka JE (2013) Microbial cultivation and the role of microbial resource centers in the omics era. Appl Microbiol Biotechnol 97(1): 51-62.

3. Tessler M. et al. (2017) Large-scale differences in microbial biodiversity discovery between $16 \mathrm{~S}$ amplicon and shotgun sequencing. Scientific Reports 7: 6589.

4. Barb JJ, Oler AJ, Kim HS, Chalmers N, Wallen GR, et al. (2016) Development of an Analysis Pipeline Characterizing Multiple Hypervariable Regions of $16 \mathrm{~S}$ rRNA Using Mock Samples. PLoS One 11(2): e0148047.

5. de Muinck EJ, Trosvik P, Gilfillan GD, Hov JR, Sundaram AYM (2017) A novel ultra-high-throughput $16 \mathrm{~S}$ rRNA gene amplicon sequencing library preparation method for the Illumina HiSeq platform. Microbiome 5(1): 68.

6. Duarte S, Cássio F, Pascoal C (2012) Denaturing gradient gel electrophoresis (DGGE) in microbial ecology - insights from freshwaters. In: Magdeldin S, (Eds,) Gel electrophoresis - principles and basics. Rijeka: In Tech, p. 173-196.

7. Tapia Estella, Andrés Donoso-Bravo, Léa Cabrol, Maria Madalena Alves, Alcina Pereira, et al (2014). A methodology for a functional interpretation of DGGE with the help of mathematical modelling. Application in bio-hydrogen production. Water Science and Technology 69(3): 511-517.

8. Benítez-Cabello A, Bautista-Gallego J, Garrido-Fernández A, Rantsiou K, Cocolin L, et al. (2016) RT-PCR-DGGE Analysis to Elucidate the Dominant Bacterial Species of Industrial Spanish-Style Green Table Olive Fermentations. Front Microbiol 7: 1291.

9. Ludeña Hinojosa Y (2007) Cianobacterias en la Bahia de Mayagüez: Abundancia, distribución y su relación con las propiedades bio-ópticas. Tesis de maestría Universidad de Puerto Rico Recinto Universitario de Mayagüez. 


\section{Advances in Biotechnology \& Microbiology}

10. Lai X, Zeng X, Fang S, Huang Y, Cao L, et al. (2006) Denaturing gradient gel electrophoresis (DGGE) analysis of bacterial community composition in deep-sea sediments of the South China Sea. World Journal of Microbiology and Biotechnology 22(12): 1337-1345.

11. Zhou J, Bruns MANN, Tiedje JM (1996) DNA recovery from soils of diverse composition. Appl Environ Microbiol 62(2): 316-322.

12. Murray MG, Thompson WF (1980) Rapid isolation of high molecular weight plant DNA. Nucleic Acids Res 8(19): 4321-4326.

13. Nübel U, Engelen B, Felske A, Snaidr J, Wieshuber A, et al. (1996) Sequence heterogeneities of genes encoding 16S rRNAs in Paenibacillus polymyxa detected by temperature gradient gel electrophoresis. Bacteriol 178(19): 5636-5643.

14. Green SJ, Leigh MB, Neufeld JD (2009) Denaturing gradient gel electrophoresis (DGGE) for microbial community analysis. In: Timmis KN, (Eds,) Handbook of Hydrocarbon and Lipid Microbiology, Springer (Heidelberg, Germany) pp 4137-4158.

15. Achenbach L, Woese C (1995) 16S and 23S rRNA-like primers. In Sowers KR, Schreier HJ, (Eds.) Cold Spring Harbor Laboratory Press, Cold Spring Harbor, NY, USA, pp. 521-523.

16. Watanabe T, Asakawa S, Nakamura A, Nagaoka K, Kimura M (2004) DGGE method for analyzing 16S rDNA of methanogenicarchaeal community in paddy field soil. FEMS Microbiol Lett 232(2): 153-163.

17. Das M, Royer TV, Leff LG (2006) Diversity of Fungi, Bacteria, and Actinomycetes on leaves decomposing in a stream. Appl Environ Microbiol 73(3): 756-767.

18. Pyrcz TW, AL Viloria, G Lamas, P Boyer (2011) La fauna de mariposas de la subfamilia Satyrinae del macizo del Ampay (Perú): diversidad, endemismo y conservación (Lepidoptera: Nymphalidae). SHILAP Revta. Lepid 39(154): 205-232.

19. Huamantupa Isau, Luza Victorio Miguel, Alfaro-Curitumay Lucero, Ururi Michel, Huaman-Arque, et al. (2017) Diversidad y Biomasa Arbórea en los Bosques Andinos del Santuario Nacional del Ampay, Apurímac-Perú. Rev Q’EUÑA 8: 7-26.

20. Felczykowska A, Krajewska A, Zielińska S, Łos JM (2015) Sampling, metadata and DNA extraction. Important steps in metagenomic studies. Acta Biochimica Pol 62(1): 151-160.

21. Lombard Nathalie, Emmanuel Prestat, Jan Dirk van Elsas, Pascal Simonet (2011) Soil-specific limitations for access and analysis of soil microbial communities by metagenomics. FEMS Microbiology Ecol 78(1): 31-49.

22. Bag S, Bipasa Saha, Bhabatosh Das (2016) An Improved Method for High Quality Metagenomics DNA Extraction from Human and Environmental Samples. Scientific Reports 6: 26775.

23. Gantner, Stephan Gantner, Anders F. Andersson, Laura Alonso-Sáez Stefan Bertilsson (2011) Novel primers for 16S rRNA-based archaeal community analyses in environmental samples. J Microbiol Methods 84(1): $12-18$

24. Hong JK, Kim HJ, Cho JC (2014) Novel PCR Primers for the Archaea Phylum Thaumarchaeota Designed Based on the Comparative Analysis of 16S rRNA Gene Sequences. PLoS ONE 9(5): e96197.

25. Fischer Martin A, Güllert Simon, Neulinger Sven C, Streit Wolfgang R, Schmitz Ruth A (2016) Evaluation of 16S rRNA Gene Primer Pairs for Monitoring Microbial Community Structures Showed High Reproducibility within and Low Comparability between Datasets Generated with Multiple Archaeal and Bacterial Primer Pairs. Front Microbiol 7: 1297.

26. Özen Asli I, Ussery David W (2012) Defining the Pseudomonas Genus: Where Do We Draw the Line with Azotobacter? Microb Ecol 63(2): 239-248.

27. Oliver JD (2005) The Viable but Nonculturable State in Bacteria. Microbiol 93-100.
28. Suzuki M, Suzuki S, Matsui M, Hiraki Y, Kawano F, et al. (2013) Genome sequence of a strain of the human pathogenic bacterium Pseudomonas alcaligenes that caused bloodstream infection. Genome Announc 1(5): e00919-13.

29. Krzeslak Joanna, Gerritse Gijs, van Merkerk Ronald, Cool Robbert H, Wim J Quax (2008) Lipase Expression in Pseudomonas alcaligenes Is Under the Control of a Two-Component Regulatory System. Appl Environ Microbiol 74(5): 1402-1411.

30. Ashengroph Morahem, Iraj Nahvi, Hamid Zarkesh-Esfahani, Fariborz Momenbeik (2011) Pseudomonas resinovorans SPR1, a newly isolated strain with potential of transforming eugenol to vanillin and vanillic acid. N Biotechnol 28(6):656-664.

31. Shintani M, Hosoyama A, Ohji S, Tsuchikane K, Takarada H, et al. (2013) Complete genome sequence of the carbazole degrader Pseudomonas resinovorans strain CA10 (NBRC 106553). Genome Announc 1(4): e 00488-13.

32. Iyer Rupa, Ikena Brian, Damaniab Ashish (2017) Genome of Pseudomonas nitroreducens DF05 from dioxin contaminated sediment downstream of the San Jacinto River waste pits reveals a broad array of aromatic degradation gene determinants. Genom Data 14: 40-43.

33. SK Shin, CY Hwang, YJ Cho, H Yi (2015) Reclassification of Serpens flexibilis Hespell 1977 as Pseudomonas flexibilis comb. nov., with Pseudomonas tuomuerensis Xin et al. 2009 as a later heterotypic synonym. Syst Appl Microbiol 38(8): 563-566.

34.Aragone MR, DM Maurizi, LO Clara, JL Navarro Estrada, A Ascione (1992) Pseudomonas mendocina, an environmental bacterium isolated from a patient with human infective endocarditis. J Clin Microbiol 30(6): 1583-1584.

35. Guo W, Wang Y, Song C, Yang C, Li Q et al. (2011) Complete genome of Pseudomonas $\mathrm{m}$ endocina NK-01, which synthesizes mediumchain-length polyhydroxyalkanoates and alginate oligosaccharides. J Bacteriol 193(13): 3413-3414

36. Zhang J, Hou H, Chen G, Wang S, Zhang J (2016) The isolation and functional identification on producing cellulase of Pseudomonas mendocina. Bioengineered 7(5): 382-391.

37. Fadel A, Mabrok M, Aly S (2018) Epizootics of Pseudomonas anguilliseptica among cultured seabream (Sparus aurata) populations: Control and treatment strategies. Microb Pathog 121: 1-8.

38. Amaike Saori, Nancy P Keller (2011) Aspergillus flavus. Annual Review of Phytopathology 49: 107-133.

39. Wei G, Tan D, Chen C, Tong Q Li XN, et al. (2017) Flavichalasines A-M cytochalasan alkaloids from Aspergillus flavipes. Sci Rep 7: 42434.

40. Guo CJ, Wang CC (2014) Recent advances in genome mining of secondary metabolites in Aspergillus terreus. Front Microbiol 5: 717.

41. Luo Z-L, et al. (2017) Molecular phylogeny and morphological characterization of asexual fungi (Tubeufiaceae) from freshwater habitats in Yunnan, China. Cryptogamie, Mycologie 38(1): 27-53.

42. Zaferanloo B, Bhattacharjee S, Ghorbani MM, Mahon PJ, Palombo EA (2014) Amylase production by Preussia minima, a fungus of endophytic origin: optimization of fermentation conditions and analysis of fungal secretome by LC-MS. BMC Microbiol 14: 55.

43. Murillo C, Albertazzi FJ, Carranza J, Lumbsch HT, Tamayo G (2009) Molecular data indicate that Rhytidhysteron rufulum (Ascomycetes, Patellariales) in Costa Rica consists of four distinct lineages corroborated by morphological and chemical characters. Mycol Res 113(Pt 4): 405-416.

44. Zhang Ying, Pedro W Crous, Conrad L Schoch, Kevin D Hyde (2011) Pleosporales. Fungal Diversity 53(1): 1-221. 
This work is licensed under Creative Commons Attribution 4.0 Licens

DOI: 10.19080/AIBM.2018.11.555811
Your next submission with Juniper Publishers will reach you the below assets

- Quality Editorial service

- Swift Peer Review

- Reprints availability

- E-prints Service

- Manuscript Podcast for convenient understanding

- Global attainment for your research

- Manuscript accessibility in different formats

( Pdf, E-pub, Full Text, Audio)

- Unceasing customer service

Track the below URL for one-step submission https://juniperpublishers.com/online-submission.php 